UDC 911:004 (075.8)

\title{
ANALYSIS OF THE RELATIONSHIPS BETWEEN MORPHOMETRIC RELIEF PARAMETERS AND VISUAL CHARACTERISTICS OF UKRAINIAN CARPATHIANS ECOSYSTEMS
}

\author{
Alexander Mkrtchian \\ Ivan Franko National University of Lviv, \\ P. Doroshenko St., 41, UA - 79007 Lviv, Ukraine, \\ e-mail: alemkrt@gmail.com
}

\begin{abstract}
The paper deals with the analysis of the relationships between the visual characteristics of mountain ecosystems as they appear on spatial images, and the characteristics of the abiotic conditions as being governed and (or) indicated by the terrain morphometric parameters, in the study area in Ukrainian Carpathians. LANDSAT 7 ETM+ spatial imagery with $30 \mathrm{~m}$ resolution, and SRTM v. 4.1 DEM with 90 m ground resolution were the main data sources used in the study. Based on the analysis of LANDSAT imagery, three principal components have been picked out that describe the different characteristics of vegetation and land cover spatial differentiation. Terrain parameters accounted for in the study included raw elevation values, flow energy index, slope values, topographic wetness index, and insolation index. The canonical correlation analysis has then been applied to analyze the relationships between the landscape reflectance characteristics, and the terrain morphometric parameters, allowing deriving two statistical significant canonical roots and determining their structure. The relationships between the structure and properties of vegetation cover (as conditioned by landscape abiotic factors and the land use structure), and the terrain morphometric parameters have thus been revealed and statistically substantiated.
\end{abstract}

Key words: LANDSAT imagery, digital elevation models, terrain morphometric parameters, factor analysis, canonical analysis.

The study of the relationships between the mountain ecosystem properties and the characteristics of their abiotic environment is very relevant from the point of natural conservation and the protection of flora and fauna species. New sources of detailed spatial data have become available nowadays for scientists and practitioners, including high-resolution spatial images of the Earth surface. The advantages of these data include the high spatial detail, temporal actuality, and digital format, allowing directly processing and analyzing data in GIS. At the same time, high-resolution spatial imagery now is widely accessible through the webservices for anyone with internet access, and many kinds of images are distributed free of charge, which is especially important for countries like Ukraine, where funding for scientific research is very limited.

Two main kinds of digital spatial layers relevant for ecological and geographical studies are digital elevation models (DEMs) and multispectral spatial imagery. The first are used to calculate a set of morphometric parameters and the related hydrologic, climatologic, and other characteristics closely linked to terrain morphometry, while the latter, characterizing reflective properties of Earth surface in different spectral bands, are the valuable source of information on natural and anthropogenic ecosystems distribution, on the state and functioning of vegetation cover, and on the distribution of land use and land cover types.

(C) Mkrtchian A., 2016 
Ukrainian Carpathians are an important regional biodiversity hotspot and the refuge and corridor for many plants and animals species, including rare and endangered ones. They provide indispensable ecosystem services and contain important areas for local and regional tourism and recreation. Article 4 of the Framework Convention on the Protection and Sustainable Development of the Carpathians (known as a Carpathian Convention, signed in 2003 in Kyiv) directs that the Parties shall pursue policies aiming at conservation, sustainable use and restoration of biological and landscape diversity throughout the Carpathians, taking appropriate measures to ensure a high level of protection and sustainable use of natural and semi-natural habitats, their continuity and connectivity. The developing of an ecological network in the Carpathians, as a constituent part of the Pan-European Ecological Network, and the establishing and supporting a Carpathian Network of Protected Areas, have been prescribed.

The complex diverse terrain and the substantial diversity in environmental conditions within relatively short distances are the factors contributing to high levels of biological diversity while also facilitate the increased fragility of geosystems and the development of hazardous processes like landslides, rockfalls, mudflows, avalanches, etc. Probably the most disturbing of these in Ukrainian Carpathians is the supposed increase in the frequency and intensity of floods hitting river floodplains where most settlements, local industry and infrastructure are located.

This study aims at the analysis and assessment of the relationship between the morphometric terrain characteristics that condition the movement and redistribution of water, solar energy, air, soluble matter and insoluble particles, and the reflectivity of landscape cover in different spectral bands, indicating the type and condition of vegetation cover, and the presence and structure of man-made features. The main data sources used in the study have been SRTM v. 4.1 DEM with $90 \mathrm{~m}$ ground resolution, and LANDSAT 7 ETM+ spatial imagery with $30 \mathrm{~m}$ resolution, taken on May 2, 2000. Study area encompasses the rectangular region of $90 \times 70 \mathrm{~km}$ dimension, located in the central part of Ukrainian Carpathians, spanning parts of northern and southern macroslopes and adjacent foothills. Data have been analyzed with a set of statistical methods, namely multiple regressions analysis, factor analysis, and canonical correlation analysis.

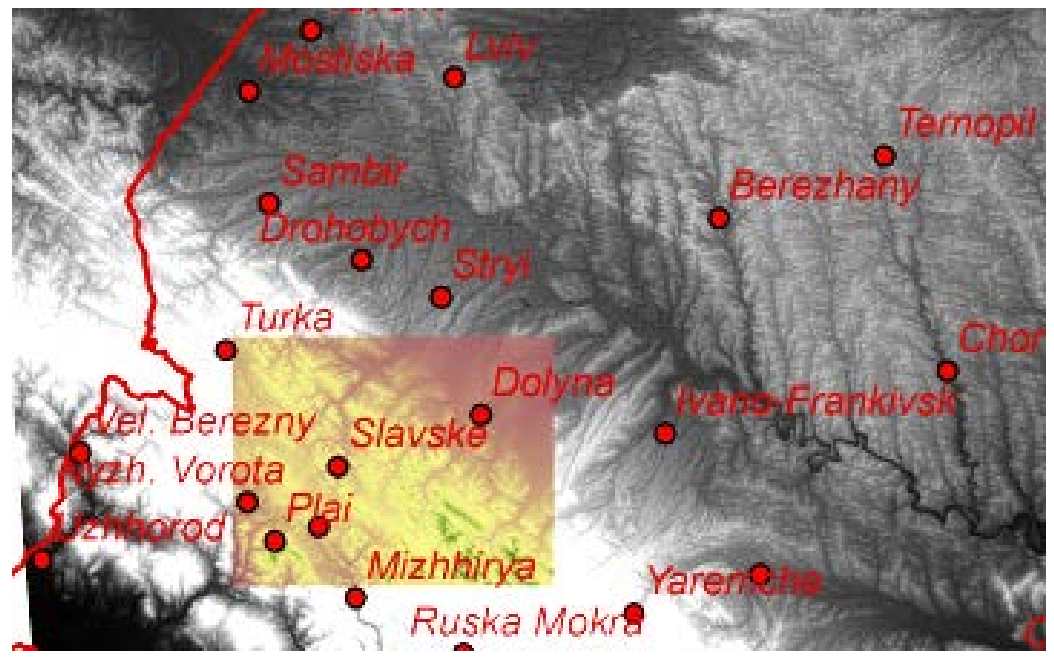

Fig. 1. Study area location

Рис. 1. Місцеположення території досліджень 
DEM has been used for the derivation of primary and secondary morphometric parameters. Primary morphometric parameters, apart from the elevation proper, included slopes, and plan and profile curvatures. Secondary morphometric parameters calculated for the study included Topographic wetness index (TWI) that relates to the water redistribution on terrain elements and the location of cite in landscape catena [2]; the index of slope flow energy relating to the erosivity of sheet-and-rill surface flow that causes the redistribution of solid matter [1]; and the insolation index that reflects the relative supply of solar energy on terrain elements of different aspect and slope values [3].

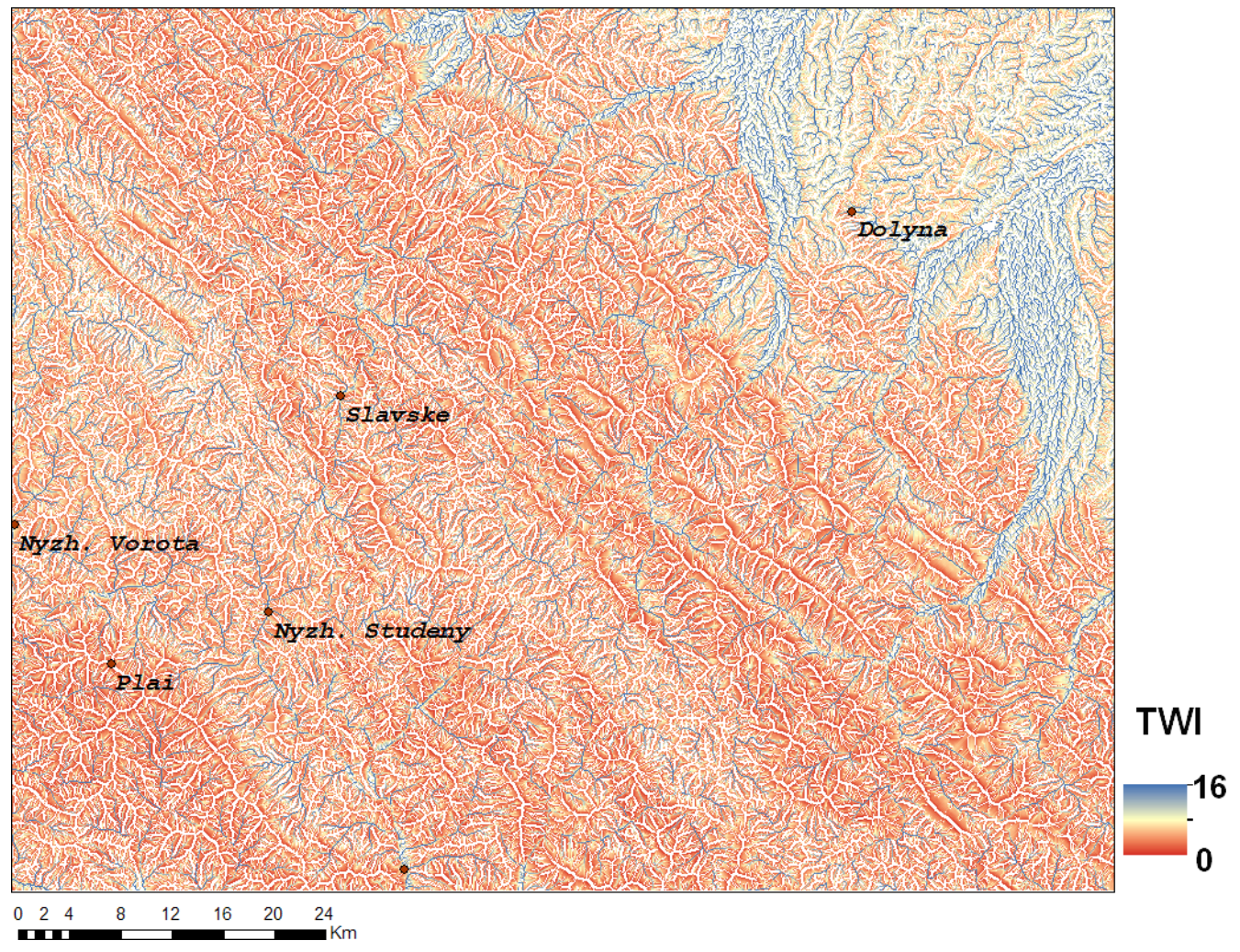

Fig. 2. Topographic wetness index (TWI) distribution

Рис. 2. Розподіл топографічного індексу вологості

Principal component analysis (a variation of factor analysis) has been applied to analyze the relationships between different bands of multispectral image. Bands 2,3,4,5 of LANDSAT 7 ETM+ have been preselected for the analysis as the most informative ones. The main mission of the principal component analysis as being applied to multispectral imagery is to reduce the effective dimensionality of a set of image bands by separating the most significant information (considered to be present on several bands) from the supposed information noise [6].

In our case the first three derived principal components have covered the $99,6 \%$ of the total spatial variability of 4 bands of the LANDSAT multispectral image. From this, the first 
principal component describes around $75 \%$ of the total variability. It represents the total "brightness" of the scene, and is highly correlated with all four image spectral bands. Its visual inspection and juxtaposition with topographic and thematic maps and layers has revealed that this component clearly shows the location and density of tree stands, featuring high values in the places where dense deciduous and coniferous tree stands are located. This component can thus be used for applied tasks of analyzing the general state of tree cover and its temporal dynamics (if image sceneries for different time periods are being analyzed).

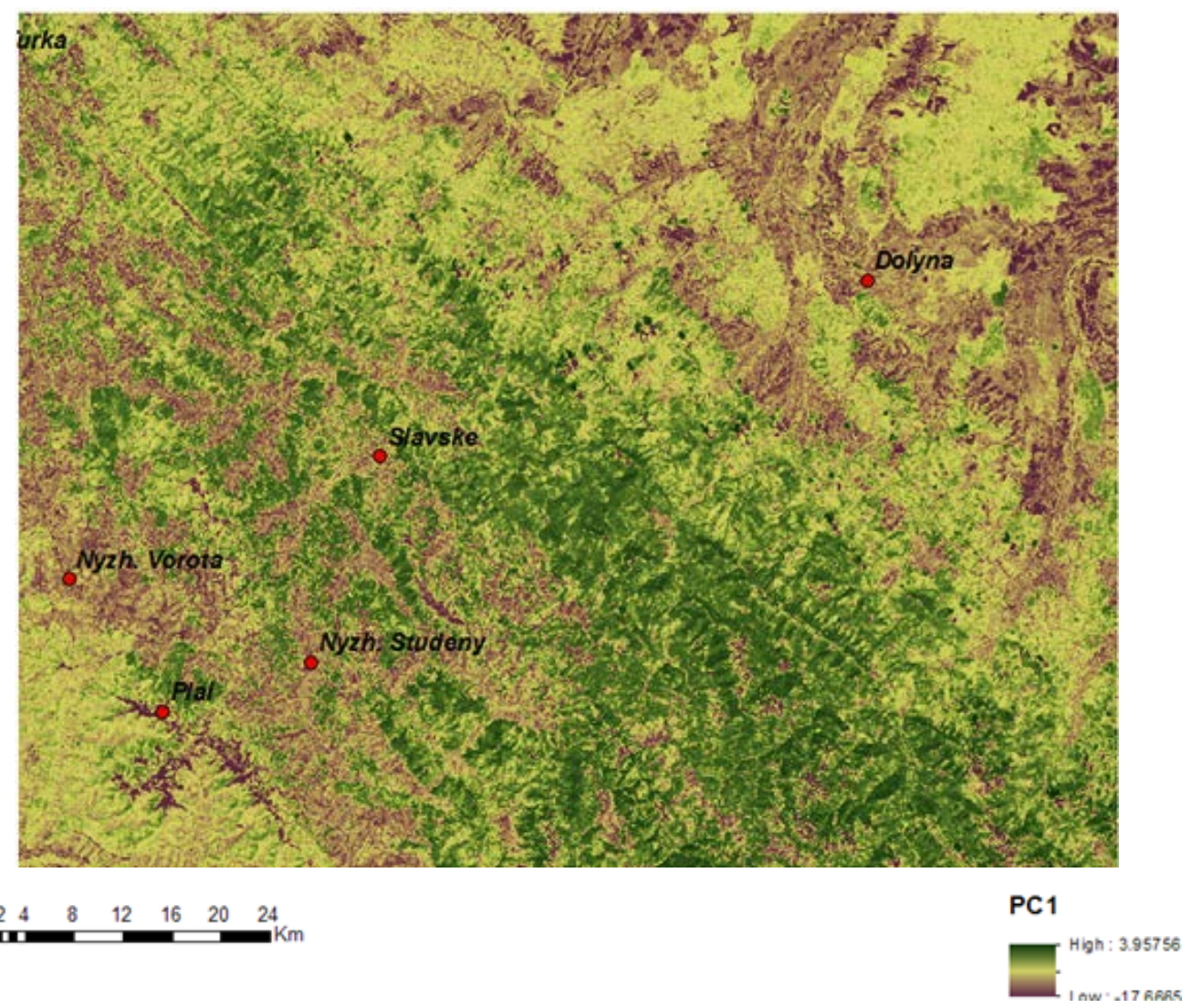

Fig. 3. Principal component 1 of LANDSAT 7 ETM+ bands 2,3,4,5

Рис. 3. Головна компонента 1, виділена за діапазонами 2,3,4,5 знімку LANDSAT 7 ETM+

The second principal component has revealed the strong negative correlation with the reflectance values in the LANDSAT band 3 (corresponds to red spectral range) and simultaneously - the positive correlation with LANDSAT band 4 (corresponds to near-infrared spectral range). It also shows very strong $(\mathbf{r}=0,95)$ correlation with the values of the Normalized Difference Vegetation Index (NDVI) introduced in 1973 and since then extensively applied in the various fields for the vegetation and landscape analyses of remotely sensed data $[4,5]$. It is calculated by following formula: 


$$
N D V I=\frac{N I R-R E D}{N I R+R E D}
$$

where RED and NIR are the reflectance values in red and near-infrared spectral ranges, respectively. It has been shown that the values of this index correlate closely with the wide set of vegetation characteristics, in particular its primary production, biomass, leaf area index, chlorophyll concentration in leafs, etc. [4] In our case the second principal component very clearly distinguishes deciduous forests (mainly of beech, Fagus sylvatica) with high values of this component, from coniferous ones (mainly of Picea abies and Abies alba), where its values are much lower. The second component also appears to be able to clearly distinguish different types of grassland vegetation, in particular - subalpic meadows showing very low values of this component, from lowland meadows where the values of second component are much higher.

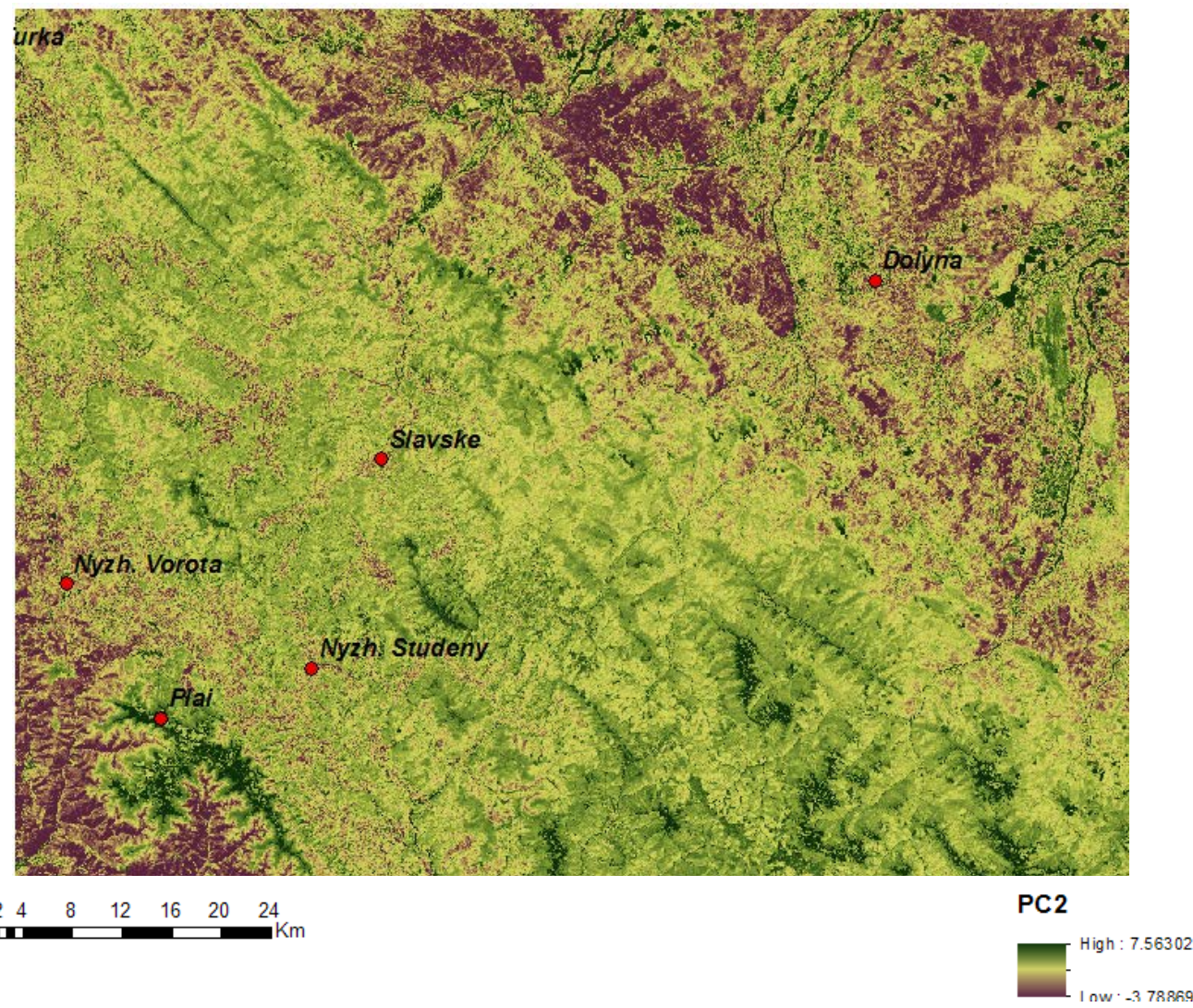

Fig. 4. Principal component 2 of LANDSAT 7 ETM+ bands 2,3,4,5

Рис. 4. Головна компонента 2, виділена за діапазонами 2,3,4,5 знімку LANDSAT 7 ETM+

Principal component three (not shown here) is relatively less informative in comparison with first two components. It, however, allows to clearly discriminate areas with subalpine shrub and grassland vegetation that show high values of this component. It generally correlates 
positively with reflectance values in LANDSAT 7 ETM+ band 2 (green), and negatively - with reflectance in band 5 (middle infrared). This component is expedient to use for the purpose of monitoring the dynamics of the extent and state of the ecologically valuable Carpathian subalpic vegetation formations.

To study the relationships between the reflectance values of landscape cover in different spectral bands and the landscape morphometric parameters the method of canonical analysis has been applied. Canonical analysis allows to study the statistical relations between two groups of values. In our case these groups have been the three principal components of LANDSAT 7 ETM+ multispectral imagery, and some of aforementioned primary and secondary morphometric parameters derived from DEM.

The calculated coefficient of canonical correlation equals 0.63 , bearing evidence of rather high degree of relationship between two groups of variables. In the process of canonical analysis the canonical roots have been derived, each of which characterizing the correlation between the two weighted sums of variables from each of the two groups. Maximal number of canonical roots equals the least number of variables in any of the two groups (in our case it equals three - the number of derived principal components of multispectral imagery). Two of the three derived canonical roots appeared to be statistically significant: root $1(\mathbf{r}=0,63)$ and root $2(\mathbf{r}=0,215)$. Table below shows the structure of canonical factors (correlation coefficients between input variables and canonical factors for three canonical roots).

Relationship between input variables and canonical roots Відношення між вхідними змінними та канонічними коренями

\begin{tabular}{|c|c|c|c|}
\hline \multicolumn{4}{|c|}{ Canonical factor structure } \\
\hline Canonical roots & Root 1 & Root 2 & Root 3 \\
\hline \multicolumn{4}{|c|}{ Morphometric parameters } \\
\hline TWI & -0.2784 & 0.277 & -0.1222 \\
\hline Elevation & 0.9788 & -0.026 & 0.1979 \\
\hline Flow energy index & 0.2386 & -0.5028 & 0.1488 \\
\hline Slope & 0.5542 & -0.7801 & 0.2583 \\
\hline Insolation index & 0.0126 & 0.4838 & 0.8725 \\
\hline \multicolumn{4}{|c|}{ Principal components of multispectral imagery } \\
\hline Component 1 & 0.6986 & -0.6937 & 0.1751 \\
\hline Component 2 & 0.7147 & 0.6883 & -0.1246 \\
\hline Component 3 & 0.0341 & -0.2122 & -0.9767 \\
\hline
\end{tabular}

As could be seen, root 1 shows the very high $(\mathbf{r}=0,98)$ correlation with absolute elevation, and rather high correlation with the first two components of multispectral imagery. Root 2 exhibits positive correlation with the second component and negative - with the first one. Thus, this root differentiates between the first principal component (the general brightness of the scene) and the second component (strongly positively correlated with NDVI and biological productivity of ecosystems). As to morphometric parameters, this root correlates negatively with slope values and terrain erosivity (Flow energy index), while being positively correlated with the relative insolation and Terrain wetness index. The third root very strongly correlates with the third principal component and with insolation. 
It can be concluded that the canonical correlation analysis applied to digital spatial data in our study allowed to reveal the structure of relationships between the main principal components of multispectral imagery and the major primary and secondary morphometric parameters. These results by implication reveal the relationships between the structure and properties of vegetation cover (as conditioned by landscape abiotic factors and the land use structure), and the characteristics of abiotic landscape components as being governed and/or indicated by the terrain morphometric parameters.

\section{REFERENCES}

1. Mkrtchian, O. (2004). Geoinformational modeling of slope erosion process. Visnyk of the Lviv University. Series Geography, 30(1), 188-193 (in Ukrainian).

2. Mkrtchian, O. (2006). Modeling of landscape-ecological characteristics distribution using topographic indices. Visnyk of the Lviv University. Series Geography, 33, 261-267 (in Ukrainian).

3. Fu, P., \& Rich, P. M. (2002). A geometric solar radiation model with applications in agriculture and forestry. Computers and Electronics in Agriculture, 37, 25-35.

4. Glenn, E. P., Huete, A. R., Nagler, P. L., \& Nelson, S. G. (2008). Relationship between remotely-sensed vegetation indices, canopy attributes and plant physiological processes: what vegetation indices can and cannot tell us about the landscape. Sensors, 8(4), 2136-2160.

5. Rouse, J. W., Haas, R. H., Schell, J. A., \& Deering, D. W. (1973). Monitoring vegetation systems in the Great Plains with ERTS. Third ERTS Symposium, NASA SP-351(I), 309-317.

6. StatSoft, Inc. (2011). Electronic Statistics Textbook. Tulsa, OK: StatSoft. URL: http://www.statsoft.com/textbook/.

\section{СПИСОК ВИКОРИСТАНОЇ ЛІТЕРАТУРИ}

1. Мкртчян О. Геоінформаційне моделювання процесу схилової ерозії // Вісн. Львів. ун-ту. Серія геогр. 2004. Вип. 30, ч. 1. С. 188-193.

2. Мкртчян $O$. Моделювання розподілу ландшафтно-екологічних характеристик 3 використанням топографічних індексів // Вісн. Львів. ун-ту. Сер. геогр. 2006. Вип. 33. С. 261-267.

3. Fu P., Rich P. M. A geometric solar radiation model with applications in agriculture and forestry // Computers and Electronics in Agriculture. 2002. N 37. P. 25-35.

4. Glenn E. P., Huete A. R., Nagler P. L., Nelson S. G. Relationship between remotely-sensed vegetation indices, canopy attributes and plant physiological processes: what vegetation indices can and cannot tell us about the landscape // Sensors. 2008. N 8(4). P. 2136-2160.

5. Rouse J. W., Haas R. H., Schell J. A., Deering D. W. Monitoring vegetation systems in the Great Plains with ERTS // Third ERTS Symposium, NASA SP-351(I). 1973. P. 309-317.

6. StatSoft, Inc. Electronic Statistics Textbook. Tulsa, OK: StatSoft. 2011. URL: http://www.statsoft.com/textbook/. 


\title{
АНАЛІЗ ЗАЛЕЖНОСТЕЙ МІЖ МОРФОМЕТРИЧНИМИ ПАРАМЕТРАМИ РЕЛЬЕФУ ТА ВІЗУАЛЬНИМИ ХАРАКТЕРИСТИКАМИ ЕКОСИСТЕМ УКРАЇНСЬКИХ КАРПАТ
}

\author{
Олександр Мкртчян \\ Львівський національний університет імені Івана Франка, \\ вул. П. Дорошенка, 41, 79007, м. Львів, Украӥна, \\ e-mail: alemkrt@gmail.com
}

\begin{abstract}
Наведено методику та результати аналізу взаємозв'язків між візуальними властивостями гірських екосистем на космознімках і характеристиками абіотичного середовища, що визначені морфометричними параметрами рельєфу, у межах ділянки Українських Карпат. Основними джерелами даних слугували космознімки LANDSAT 7 ETM+ 3 роздільною здатністю 30 м, та цифрова модель рельєфу SRTM v. 4.1 з роздільною здатністю 90 м. На підставі аналізу космознімків виділено три головні компоненти, які відповідають різним характеристикам просторової диференціації рослинності та наземного покриву. Морфометричні параметри, використані в дослідженні, охоплювали значення абсолютної висоти, індексу енергії схилових потоків, крутості схилів, топографічного індексу вологості та індексу інсоляції. Для аналізу взаємозв'язків між відображеними на космознімках характеристиками відбивної здатності та морфометричними показниками рельєфу використано метод канонічного аналізу, який дав змогу виділити два статистично значимі канонічні корені і визначити структуру канонічних чинників.

Ключові слова: космознімки LANDSAT, цифрові моделі рельєфу, морфометричні параметри рельєфу, факторний аналіз, канонічний аналіз.
\end{abstract}

